BENHA VETERINARY MEDICAL JOURNAL, VOL. 34, No. 3: 330-337, AUGUST 2018 A SPECIAL ISSUE FOR THE $6^{\text {TH }}$ SCIENTIFIC INTERNATIONAL CONFERENCE

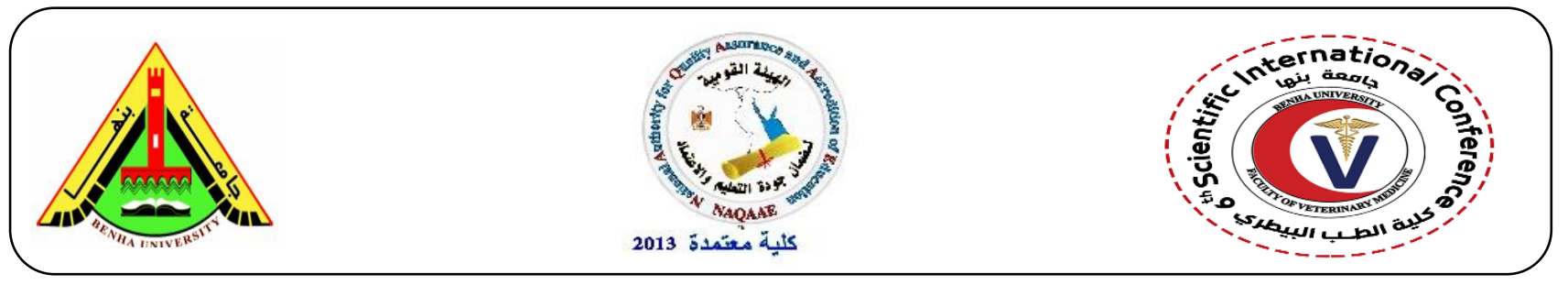

\title{
Effect of sun dried tomato pomace( SDTP) supplementation on productive and economic efficiency of laying Japanese Quail
}

\author{
Seham Fawzy Shehata ${ }^{1 *}$, Eman Ramadan Kamel ${ }^{1}$, Mohammed El-Sayed Abo-Salem ${ }^{2}$ and \\ Sanad Talaat Atallah ${ }^{3}$ \\ 1- Department of Animal Wealth Development, Faculty of Veterinary Medicine, Benha University. \\ 2- Department of Forensic Medicine and Toxicology, Faculty of Veterinary Medicine, Benha University. \\ 3- Department of Animal Husbandry and Animal Wealth Development, Faculty of Veterinary Medicine, \\ Alexandria University. \\ "Correspondence should be addressed: E-mail: seham.shehata@fvtm.bu.edu.eg
}

\section{A B S T R A C T}

This work was conducted to study the effect of sun dried tomato pomace (SDTP) with or without enzymes supplementation on productive and economic efficiency of laying Japanese hens. A total of 144 forty-two- days-old female Japanese quails were used. The hens were randomly allocated into 6 groups (24 hens per each group which subdivided into 3 replicates each one contains 8 females.). Group 1 was fed on the basal diet (BD) (control), Group 2 were fed on the BD containing AveMix® $02 \mathrm{CS}$ enzyme $0.2 \mathrm{~g} / \mathrm{kg}$ diet. While hens of group 3 were fed BD containing $2.5 \%$ SDTP. Group 4 received BD containing 2.5\% SDTP with AveMix ${ }^{\circledR} 02 \mathrm{CS}$ enzyme. Group 5 received BD containing 5\% SDTP. Group 6 received BD containing 5\% SDTP with AveMix® 02 CS enzyme. From the obtained results, it was observed that addition of different levels of SDTP not affected significantly daily egg production. The greatest egg mass was for (5\%) SDTP with enzymes group (281.57 gm)/ bird. While the lowest egg mass was for (5\%) SDTP group (247.41 gm) egg/ bird. feeding different concentrations of SDTP with or without enzyme showed a non- significant effect on carcass traits in laying hens. The feed cost, Total Variable Cost (TVC) and Total Cost (TC) were high for the control group (367.63, 1084.88 and 1288.88 piasters); respectively. While, they were low for (5\%) SDTP group (285.49, 990.84 and 1194.84 piasters); respectively. The highest Net Return (NR) value was found for (2.5\%) SDTP group (381.25piasters) while the lowest one was found for (5\%) SDTP group and control group (310.66, 310.84 piasters); respectively.

Keywords: Laying Japanese quail, Tomato pomace, Enzymes, Productive efficiency, Economic efficiency.

\section{INTRODUCTION}

Raising Japanese quail for food regarded as another dimension of poultry farming as a result of shortage of animal protein through the increasing availability of eggs and meat in developing countries Agiang et al. (2011). Also, Ayaşan (2013) mentioned that the 
Japanese quail had acquired its economic importance as is the smallest avian species which produce eggs and meat that enjoyed for their unique flavor. Tunsaringkarn et al. (2013) stated that quail eggs are the good source of nutrients for human health. Regular consumption of quail eggs helps fight against many diseases which are a natural combatant against digestive tract disorders such as gastritis. Quail eggs improve the immune system, promote memory health, increase brain activity and stabilize the nervous system. Rising costs of cereals and imported feedstuffs for poultry diets have resulted in a search for alternative ingredients that would be available as by-products from local agricultural industries as said by Adeniji and Oyeleke (2008). In addition, Agro-Industrial ByProducts (AIBP) represented one of the most talented, promising energy and protein sources supply for livestock. The use of AIBP as a part of the feed for livestock has a high value starting from reducing the cost of production and ultimately increasing the profit margin of livestock farmers Salajegheh et al. (2012). Tomato and Tomato by-products are excellent sources of protein, fat, vitamin $\mathrm{E}$ and minerals such as nitrogen, iron, and zinc which some of them have antioxidant properties as reported by Alshatwi et al. (2010). Therefore, this study was carried out to investigate the effect of diets containing two levels (2.5 and 5\%) of SDTP with or without AveMix® 02 CS enzyme on egg production traits, carcass traits in laying peiod and economic efficiency in laying peiod.

\section{2-MATEREAL AND METHODS}

\subsection{Experimental Chicks:}

Our study was carried out at the quail production unit of the faculty of veterinary medicine Moshtohor, Benha University, at the period extended from 11th April 2015 to 30th may. A total of 144 forty- two- day old Japanese hens were used in this study. In which each group contains 24 females which subdivided into (3) replicates each one contains 8 females.

\subsection{Management and Housing:}

The hens housed in 2 battery cages; each cage consisted of 10 departments. They were housed in a clean well-ventilated room, previously disinfected with formalin. The hens were housed in a clean well-ventilated room. Feed and water were supplied ad-libitum.

\subsection{Experimental Diets:}

2.3.1. Tomato pomace obtained from commercial processors (Hienz company, 6th October City, Egypt). It dried by spreading on a plastic sheet with exposing to sunlight. The particle size of pomace reduced by beating using stick and hand crushing according to Yitbarek (2013).

\subsubsection{Enzyme description:}

AveMix ${ }^{\circledR} 02$ CS enzyme, a commercial multi enzyme containing glucanase, endo-1,4$\beta$-xylanase and pectinase added to enzyme supplemented diet at the rate of $0.2 \mathrm{~g} / \mathrm{kg}$ diet. Hens were randomly sorted into six experimental groups and were fed adlibitum on the 6 different experimental diets until the end of the experiment.

\subsection{Studied traits:}

2.4.1. Feed intake (FI) was estimated as the difference between offered feed and refused portion as Melkamu et al. (2011).

2.4.2. Feed conversion ratio /Egg mass (FCR) was calculated by dividing the amount of feed consumed in grams (by a bird) during the week by the egg mass in grams (of the same hen) during the same week (Jalalinasab et al. 2014).

2.4.3. Egg number and Egg weight were recorded for each replicate weekly according to Tahmasbi et al. (2012).

2.4.4. Egg mass: The average egg weight (g) for each replicate multiplied by the egg number weekly calculated according to Jalalinasab et al. (2014). 
2.4.5. Evaluation of carcass parameters for laying birds: -

At the end of 12th week of age, live weight of birds was taken before slaughtering immediately, Heart, gizzard, liver, spleen weights recorded of each bird were weighed according to Brake et al. (1993).

2.4.6. Economic efficiency measurements:

2.4.6.1. Total costs (TC): It was calculated from the summation of total fixed costs and total variable costs.

Total costs $=$ Total fixed costs + Total variable costs.

2.4.6.2. Total returns (TR):

- Total returns $=$ Litter sale + egg sale+ hen sales.

- Litter sale $=$ Litter sale price / No. of quail at the end of the project.

- Egg sale = number of eggs $\mathrm{x}$ price of an egg.
- Hen sale = Body weight/gm at the end of project $x$ Gram price.

2.4.6.3. Net Profit: It was calculated according to Nwajiuba and Nwoke (2001) using the following equation: Net profit $=$ Total returns - Total costs

\section{3- RESULTS}

1- Effect of different diets on FI/Hen/Day, EP /day\%, Average egg wt, average FCR egg mass, total number of egg per hen and average egg weight in Laying quail (Mean \pm SE).

2- Effect of different diets on carcass traits of Laying quail (Mean $\pm \mathrm{SE}$ ).

3- Effect of different diets on feed cost, dietary supplement cost, price of bird at start, TVC, TFC, TC, bird sale, egg sale, Litter Sale, Total Return and Net Return (NR) (piaster/bird) in laying quail (Mean $\pm \mathrm{SE}$ ).

Table (1): Effect of different diets on FI/Hen/Day, EP /day\%, Average egg wt, average FCR egg mass, total number of egg per hen and average egg weight in Laying quail (Mean $\pm \mathrm{SE}$ ).

\begin{tabular}{|c|c|c|c|c|c|c|}
\hline Items & $\begin{array}{c}\text { C } \\
\text { Mean } \pm \text { Std. Error }\end{array}$ & $\begin{array}{c}\text { C+Enzyme } \\
\text { Mean } \pm \text { Std. } \\
\text { Error }\end{array}$ & $\begin{array}{c}2.5 \% \text { SDTP } \\
\text { Mean } \pm \text { Std. } \\
\text { Error }\end{array}$ & $\begin{array}{c}2.5 \% \text { SDTP+Enz } \\
\text { Mean } \pm \text { Std } \\
\text { Error }\end{array}$ & $\begin{array}{c}\text { 5\%SDTP } \\
\text { Mean } \pm \\
\text { Std. Error }\end{array}$ & $\begin{array}{c}\text { 5\% SDTP+Enz } \\
\text { Mean } \pm \text { Std. } \\
\text { Error }\end{array}$ \\
\hline FI/HEN/DAY & $26.52^{b} \pm 0.81$ & $27.48^{a} \pm 0.42$ & $27.15^{\mathrm{ab}} \pm 0.68$ & $27.74^{\mathrm{a}} \pm \mathbf{0 . 7 8}$ & $26.64^{b} \pm 0.66$ & $28.29^{a} \pm 0.47$ \\
\hline EP /DAY \% & $60.12^{\mathrm{a}} \pm 2.11$ & $57.34^{\mathrm{a}} \pm 2.32$ & $57.84^{\mathrm{a}} \pm 1.54$ & $50.20^{a} \pm 1.69$ & $52.58^{\mathrm{a}} \pm 1.54$ & $60.02^{\mathrm{a}} \pm 2.36$ \\
\hline Average Egg WT & $10.40^{\mathrm{d}} \pm 0.09$ & $11.25^{b} \pm 0.03$ & $11.18^{\mathrm{c}} \pm 0.05$ & $11.47^{\mathrm{a}} \pm 0.04$ & $11.36^{\mathrm{ab}} \pm 0.04$ & $11.23^{b} \pm 0.02$ \\
\hline $\begin{array}{l}\text { Average FCR } \\
\text { egg mass }\end{array}$ & $4.70^{\mathrm{ab}} \pm 0.24$ & $4.88^{\mathrm{ab}} \pm 0.24$ & $4.49^{b} \pm 0.20$ & $5.07^{a} \pm 0.15$ & $4.81^{\mathrm{ab}} \pm 0.17$ & $4.82^{\mathrm{ab}} \pm 0.27$ \\
\hline $\begin{array}{l}\text { Total number } \\
\text { Egg }\end{array}$ & $25.25^{a} \pm 0.89$ & $24.08^{\mathrm{ab}} \pm 0.98$ & $24.25^{\mathrm{ab}} \pm 0.65$ & $22.71^{b} \pm 0.61$ & $22.08^{b} \pm 0.65$ & $25.21^{\mathrm{a}} \pm 0.99$ \\
\hline
\end{tabular}

Means within the same row carrying different superscript are significant at $(p \leq 0.05)$. 
Table (2): Effect of different diets on carcass traits of Laying quail (Mean $\pm \mathrm{SE}$ ).

\begin{tabular}{|c|c|c|c|c|c|c|}
\hline Items & $\begin{array}{c}\text { C } \\
\text { Mean } \pm \text { Std. } \\
\text { Error }\end{array}$ & $\begin{array}{c}\text { C+Enzyme } \\
\text { Mean } \pm \text { Std. } \\
\text { Error }\end{array}$ & $\begin{array}{r}2.5 \% \text { SDTP } \\
\text { Mean } \pm \text { Std. Error }\end{array}$ & $\begin{array}{c}2.5 \% \text { SDTP+Enz } \\
\text { Mean } \pm \text { Std. } \\
\text { Error }\end{array}$ & $\begin{array}{c}\text { 5\%SDTP } \\
\text { Mean } \pm \text { Std. Error }\end{array}$ & $\begin{array}{l}\mathbf{5 \%} \text { SDTP+Enz } \\
\text { Mean } \pm \text { Std. Error }\end{array}$ \\
\hline $\begin{array}{l}\text { life bird } \\
\text { weight }\end{array}$ & $237.20^{\mathrm{a}} \pm 13.06$ & $241.20^{\mathrm{a}} \pm 20.83$ & $246.40^{\mathrm{a}} \pm 13.26$ & $246.80^{\mathrm{a}} \pm 7.58$ & $234.80^{\mathrm{a}} \pm 13.94$ & $232.00^{\mathrm{a}} \pm 5.40$ \\
\hline $\begin{array}{l}\text { Dressed } \\
\text { carcass wt }\end{array}$ & $164.00^{\mathrm{a}} \pm 9.78$ & $171.60^{\mathrm{a}} \pm 14.05$ & $164.80^{\mathrm{a}} \pm 11.24$ & $172.80^{\mathrm{a}} \pm 5.16$ & $167.60^{\mathrm{a}} \pm 10.53$ & $159.20^{\mathrm{a}} \pm 3.38$ \\
\hline liver wt & $8.00^{\mathrm{a}} \pm 0.45$ & $8.00^{\mathrm{a}} \pm 0.63$ & $7.20^{\mathrm{a}} \pm 0.49$ & $8.60^{\mathrm{a}} \pm 0.25$ & $7.40^{\mathrm{a}} \pm 0.93$ & $8.00^{\mathrm{a}} \pm 0.55$ \\
\hline heart wt & $2.60^{\mathrm{a}} \pm 0.40$ & $3.00^{\mathrm{a}} \pm 0.45$ & $2.80^{\mathrm{a}} \pm 0.37$ & $3.60^{\mathrm{a}} \pm 0.40$ & $3.40^{\mathrm{a}} \pm 0.25$ & $3.40^{\mathrm{a}} \pm 0.40$ \\
\hline gizzard wt & $6.60^{\mathrm{a}} \pm 0.60$ & $6.60^{\mathrm{a}} \pm 0.60$ & $5.20^{\mathrm{a}} \pm 0.49$ & $6.40^{\mathrm{a}} \pm 0.40$ & $6.80^{\mathrm{a}} \pm 0.49$ & $5.60^{\mathrm{a}} \pm 0.40$ \\
\hline spleen wt & $0.42^{\mathrm{a}} \pm 0.04$ & $0.38 \pm 0.04$ & $0.44^{\mathrm{a}} \pm 0.02$ & $0.34^{\mathrm{a}} \pm 0.02$ & $0.42^{\mathrm{a}} \pm 0.06$ & $0.40^{\mathrm{a}} \pm 0.03$ \\
\hline
\end{tabular}

Means within the same row carrying different superscript are significant at $(p \leq 0.05)$.

Table (3): Effect of different diets on feed cost, dietary supplement cost, price of bird at start, TVC, TFC, TC, bird sale, egg sale, Litter Sale, Total Return and Net Return (NR) (piaster/bird) in laying quail (Mean \pm SE).

\begin{tabular}{|c|c|c|c|c|c|c|}
\hline Items & $\begin{array}{c}\text { C } \\
\text { Mean } \pm \text { Std. } \\
\text { Error }\end{array}$ & $\begin{array}{c}\text { C+Enzyme } \\
\text { Mean } \pm \text { Std. } \\
\text { Error }\end{array}$ & $\begin{array}{c}2.5 \% \text { SDTP } \\
\text { Mean } \pm \text { Std. Error }\end{array}$ & $\begin{array}{l}\text { 2.5\%SDTP+Enz } \\
\text { Mean } \pm \text { Std. Error }\end{array}$ & $\begin{array}{c}\text { 5\%SDTP } \\
\text { Mean } \pm \text { Std. Error }\end{array}$ & $\begin{array}{c}\text { 5\% SDTP+Enz } \\
\text { Mean } \pm \text { Std. } \\
\text { Error }\end{array}$ \\
\hline Feed cost & $367.63^{\mathrm{a}} \pm 11.20$ & $325.44^{b} \pm 5.00$ & $311.40^{a b} \pm 7.79$ & $296.38^{\mathrm{c}} \pm 8.34$ & $285.49^{\mathrm{d}} \pm 7.07$ & $291.14^{\mathrm{cd}} \pm 4.79$ \\
\hline $\begin{array}{l}\text { Dietary } \\
\text { supplemen } \\
\text { t cost }\end{array}$ & ----- & $0.25^{\mathrm{e}}$ & $2.85^{\mathrm{d}} \pm 0.07$ & $35.23^{b} \pm 0.99$ & $5.59^{c} \pm 0.14$ & $71.59^{\mathrm{a}} \pm 1.18$ \\
\hline Bird sale & $717.25^{\mathrm{a}} \pm 12.58$ & $700.00^{\mathrm{a}} \pm 8.32$ & $694.50^{\mathrm{a}} \pm 12.80$ & $720.50^{\mathrm{a}} \pm 8.83$ & $699.75^{\mathrm{a}} \pm 9.99$ & $702.50^{\mathrm{a}} \pm 10.16$ \\
\hline TVC & $1084.88^{\mathrm{a}} \pm 21.15$ & $1025.69^{b c} \pm 11.34$ & $1008.75^{c} \pm 16.40$ & $1052.11^{b} \pm 15.15$ & $990.84^{\mathrm{d}} \pm 14.84$ & $1065.23^{\mathrm{ab}} \pm 10.59$ \\
\hline TFC & 204 & 204 & 204 & 204 & 204 & 204 \\
\hline TC & $1288.88^{\mathrm{a}} \pm 21.15$ & $1229.69^{b c} \pm 11.34$ & $1212.75^{c} \pm 16.40$ & $1256.11^{b} \pm 15.15$ & $1194.84^{\mathrm{d}} \pm 14.84$ & $1269.23^{\mathrm{ab}} \pm 10.59$ \\
\hline bird sale & $818.22^{b} \pm 11.89$ & $839.63^{a b} \pm 11.21$ & $840.00^{\mathrm{ab}} \pm 12.42$ & $868.44^{\mathrm{a}} \pm 11.55$ & $819.00^{\mathrm{ab}} \pm 9.01$ & $819.00^{b} \pm 9.01$ \\
\hline egg sale & $757.50^{\mathrm{a}} \pm 26.55$ & $722.50^{\mathrm{ab}} \pm 29.28$ & $730.00^{\mathrm{ab}} \pm 19.42$ & $681.25^{c} \pm 18.28$ & $662.50^{c} \pm 19.36$ & $756.25^{\mathrm{a}} \pm 29.78$ \\
\hline litter sale & 24 & 24 & 24 & 24 & 24 & 24 \\
\hline TR & $1599.72^{\mathrm{a}} \pm 60.43$ & $1586.13^{\mathrm{a}} \pm 31.34$ & $1594.00^{\mathrm{a}} \pm 55.07$ & $1537.69^{b} \pm 53.62$ & $1505.5^{\mathrm{a}} \pm 53.64$ & $1599.25^{a} \pm 31.36$ \\
\hline NR & $310.84^{\mathrm{c}} \pm 11.52$ & $356.44^{\mathrm{ab}} \pm 34.63$ & $381.25^{\mathrm{a}} \pm 11.04$ & $317.58^{b} \pm 13.31$ & $310.66^{\mathrm{c}} \pm 13.14$ & $330.02^{\mathrm{ab}} \pm 33.30$ \\
\hline
\end{tabular}

Means within the same row carrying different superscript are significant at $(p \leq 0.05)$. 
Table (4): Chemical composition of experimental diets for laying quail.

$\begin{array}{lcccccc}\text { Item } & \mathrm{C} & \mathrm{D} 1 & \mathrm{D} 2 & \mathrm{D} 3 & \mathrm{D} 4 & \mathrm{D5} \\ \text { Crude Protein } & 20.01 & 20.00 & 19.97 & 20.00 & 20.00 & 19.99 \\ \text { MEn Kcal / kg } & 2,900 & 2,903 & 2,903 & 2,899 & 2,897 & 2,898 \\ \text { Crude Fiber } & 3.25 & 3.27 & 3.65 & 3.67 & 4.06 & 4.07 \\ \text { Lysine } & 1.01 & 1.00 & 1.00 & 1.00 & 1.02 & 1.01 \\ & & & & & \\ \text { Methionine } & 0.45 & 0.45 & 0.45 & 0.45 & 0.45 & 0.45 \\ \begin{array}{l}\text { Methionine + } \\ \text { Cystine }\end{array} & 0.81 & 0.81 & 0.80 & 0.79 & 0.78 & 0.78 \\ \begin{array}{l}\text { Threonine } \\ \text { Calcium }\end{array} & 0.73 & 0.73 & 0.73 & 0.73 & 0.73 & 0.73 \\ \begin{array}{l}\text { Available } \\ \text { Phosphorus }\end{array} & 2.51 & 2.49 & 2.50 & 2.49 & 2.51 & 2.52 \\ \text { Chloride } & 0.45 & 0.44 & 0.45 & \text { s } 0.45 & 0.46 & 0.45 \\ \text { Sodium } & 0.22 & 0.22 & 0.22 & 0.22 & 0.22 & 0.22 \\ \text { True digestible } & 0.17 & 0.17 & 0.17 & 0.17 & 0.17 & 0.17 \\ \text { phosphorus } & 0.30 & 0.30 & 0.30 & 0.30 & 0.30 & 0.30 \\ \text { Phytate } & 0.26 & 0.27 & 0.87 & 0.24 & 0.24 & 0.24\end{array}$

\section{DISCUSSION}

In regard to table (1), the highest total FI value recorded was for (5\%) SDTP group (1188.71 gm) per bird, While, the lowest value FI found was for control group (1114.04 gm) per bird. This result agreed with Calislar and Uygur (2010) who found that the inclusion of DTP increased the FI in laying hen. But our results disagreed with Tarasewicz and Aniśko (2015) who stated that the inclusion of DTP in diets did not affect feed intake.

Daily egg production not affected significantly by different experimental diets. It ranged from (50.20 to $60.12 \%$ ). This result is in accordance to Habanabashaka et al. (2014) who concluded that feeding laying hens' diets containing TP at inclusion did not affect EP. But it disagreed with Khan et al. (2011) who mentioned that enzyme supplementation to the basal diet significantly improved $(p<0.05)$ the egg production.

The average egg weight was high for (2.5\%) SDTP with Enzymes group (11.47 $\mathrm{gm})$. But it was low for the control group (10.40 gm). Our finding is in agreement with Nobakht and Safamehr (2007) reported that feeding hen diets containing DTP at inclusion rates up to $10 \%$ increased EW this may influence by supplying high levels of nutrients especially some amino acids like lysine and higher FI with the inclusion of DTP in laying hen diets. Also, this result agreed with Vasupen et al. (2013) who found that 
Enzymes supplementation in laying hen diet increased yolk weight which leads to increase egg weight.

Average FCR egg mass value was high for (2.5\%) SDTP plus Enzymes group (5.07), but it was low for (2.5\%) SDTP group (4.49). This result may be enzymes addition. Our finding agreed with Khan et al. (2011) who mentioned that enzyme supplementation in the diet leads to improving FCR in laying hens.

The greatest number of eggs was high for the control group followed by (5\%) SDTP plus enzymes group then (2.5\%) SDTP group (25.25, 25.21 and 24.25) respectively egg/ bird. While the number of eggs was low for (5\%) SDTP group (22.08) egg/ bird. This result is in accordance to Safamehr et al. (2011) who found that the reason for the decline in egg production because of increasing DTP was related to the value of fiber in these diets and consequently reduction in digestibility of nutrients.

Concerning table (2), it was noticed that feeding different concentrations of SDTP with or without enzyme showed a non- significant effect of experimental diets on life weight of the bird, dressed carcass weight, liver weight, heart weight, gizzard weight, and spleen weight in laying quail. Our finding is in the same line to Yitbarek (2013) who found that including tomato pomace at different levels gave no significant differences in carcass yield.

Regarding table (3), the feed cost was high for the control group (367.63 piasters). While, it was low for (5\%) SDTP group (285.49 piasters). This result consistent with the previous results reported by Vasupen et al. (2013) who said that additional of dietary tomato pomace to poultry diets had reduced capital costs for egg production. Also, this result is in the same line with Yitbarek (2013) who stated that there is an inverse relationship between the inclusion of DTP in growers ration and feed cost per kg feed.

But dietary supplement cost was high for (5\%) SDTP with enzymes (71.59 piasters). It was low for control group supplemented with enzyme ( 0.25 piaster). This result due to the cost of SDTP plus enzymes is more than the cost of enzymes only.

TVC and TC were high in the control group (1084.88 and 1288.88 piasters) respectively. They were low in 5\% SDTP group (990.84 and 1194.84 piasters); respectively. These results agreed with Pathakamuri (2014) who reported that feed cost per kg gain showed significantly $(\mathrm{P}<0.01)$ decrease with more increase in the level of DTP inclusion. And Anuradha and Roy (2015) indicated that feed cost is about 60 to $80 \%$ of the total cost of production. In addition to Sayed and Abdel-Azeem (2009) concluded that addition of tomato pomace to the diet decrease TC for substituted group compared to the control diet.

The highest price for quail was found for (2.5\%) SDTP plus Enzymes group (868.44 piasters) while, the lowest one was found for control group (818.22 piasters). This is due to higher weight of these birds. This finding was in arrangement with Jouzi et al. (2015) who showed that dried tomato pulp used as an ingredient in quails ration up to the level of 4$6 \%$ without harming weight gain.

Egg selling was high for the control group (757.50 piasters) followed by (5\%) SDTP plus enzymes group (756.25 piasters) while, it was low for (5\%) SDTP group (662.50 piasters). That is due to higher weight of these birds. That may be attributable to more number of egg in control than (5\%) SDTP group.

The highest NR value was found for $(2.5 \%)$ SDTP group (381.25piasters) while, the lowest one was found for (5\%) SDTP group and control group (310.66, 310.84 piasters) respectively. That is due to higher weight of 
these birds and egg sale was higher for $(2.5 \%)$ SDTP group. This result was in the same line with Yitbarek (2013) who showed that DTP can be used decrease the production cost and maximizes profit without deleterious effect on the overall performance of grower chicks, so it increases the economic efficiency. There was non-significant difference among different experimental diets on total return in laying quails.

\section{Conclusion:}

It is concluded that using diets containing SDTP in laying quails leads to higher average egg weight and higher NR in laying stage. Also, using diets containing SDTP with enzymes group leads to higher egg mass per bird and lower feed cost in laying stage.

\section{References:}

Agiang, E. A.; Oko, O.O.K. and Essien, G. E. (2011): Quails Response to Aqueous Extract of Bush Marigold (Aspilia africana) Leaf. American Journal of Animal and Veterinary Sciences 6 (4): 130-134.

Alshatwi, A. A.; Al Obaaid, M.A.P.; Al Sedairy, S. A.; Al-Assaf, A. H.; Zhang, J. J. and Lei, K.Y.(2010): Tomato powder is more protective than lycopene supplement against lipid peroxidation in rats. Nutr. Res. 30:66-73.

Anuradha, P. and Roy, B. (2015): Effect of Supplementation of Fiber Degrading Enzymes on Performance of Broiler Chickens Fed Diets Containing DeOiled Rice Bran. Asian Journal of Animal and Veterinary Advances 10 (4): 179-184.

Ayaşan, T (2013): Effects of dietary inclusion of protexin (probiotic) on hatchability of Japanese quails. Ind. J. Anim. Sci., 83(1): 78-81.

Brake, J.; Havenstein, B.; Scheideler, S E.; Ferket, B.R. and Rives, D.V. (1993): Relationship of sex, age and body weight to broiler carcass yield and offal production. Poult. Sci.,72: 1137 1145.

Calislar, S. and Uygur, G. (2010): Effects of dry tomato pulp on egg yolk pigmentation and some egg yield characteristics of laying hens. J. Anim. Vet. Adv. 9(1):96-98.

Habanabashaka, M.; Sengabo, M. and Oladunjoye, I.O. (2014): Effect of Tomato Waste Meal on Lay Performance, Egg Quality, Lipid Profile and Carotene Content of Eggs in Laying Hens. Iranian Journal of Applied Animal Science. 4(3), 555559.

Jalalinasab, A.; Nobakht, A. and Razzaghzadeh, S. (2014): The Effects of Different Levels of Tomato Pomace and Processing Methods on Production Performance and Blood Metabolites of Native Laying Hens. Iranian Journal of Applied Animal Science. Volume: 4; Number: 2; Pages: 379-385.

Jouzi, H.; Vali, N. and Pourreza, J. (2015): The effects of Tomato pulp powder Supplementation on performance and some Blood Parameters In Japanese Quail(Coturnix Japonica). Journal of Agricultural and Biological Science. Vol. 10, NO. 3,103-107.

Khan,S. H.; Atif, M.; Nasir Mukhtarb, N.; Rehman, A. and Fareed, G. (2011): Effects of supplementation of multienzyme and multi-species probiotic on production performance, egg quality, cholesterol level and immune 
system in laying hens. Journal of Applied Animal Research, Vol. 39, No. 4, 386_398.

Melkamu, B.; Yayneshet, B.T. and Alemayehu, T. (2011): Performance of Growing Rhode Island Red Chicks Fed Different Levels of Dried Tomato Pomace and a Commercial Diet. Journal of the Drylands. 4 (2): 320-324.

Nwajiuba, C. and Nwoke, E. (2001): Comparative analysis of the economics of conventional and nonconventional feed use by poultry enterprises in Owerri, Nigeria. Journal of Agriculture in the Tropics and Subtropics Volume 102, No. pp. $153-160$.

Nobakht, A. and Safamehr, A.R. (2007): The effect of inclusion different levels of dried tomato pomace in laying hens diets on performance and plasma and egg yolk cholesterol content. J of Anim \& Vet Advances, 6 (9) :11011106.

Pathakamuri, K. (2014): Tomato pomace: Alternative feed resource for poultry. J Veterinar Sci Technolo 2014 Volume 5, Issue 3 . Page 48.

Safamehr, A.; Malek, H. and Nobakht, A. (2011): The effect of different levels of tomato pomace with or without multi enzyme on performance and egg traits of laying hens. Iranian J.Anim.Sci. 1(1), 39-48.

Salajegheh, M.H.; Ghazi, S.; Mahdavi, R. and Mozafari, O. (2012): Effects of different levels of dried tomato pomace on performance, egg quality and serum metabolites of laying hens. African Journal of Biotechnology Vol. 11(87), pp. 15373-15379.

Sayed, A.N. and Abdel-Azeem, A.M. (2009): Evaluation of Dried Tomato Pomace as Feedstuff in the Diets of Growing Rabbits. IJAVMS Vol. 3, 12-18.

Tahmasbi, A. M.; Mirakzehi, M.T.; Hosseini, S.J.; Agah, M.J. and Kazemi, F. M. (2012): The effects of phytase and root hydroalcoholic extract of Withania somnifera on productive performance and bone mineralisation of laying hens in the late phase of production. British Poultry Science, 53: 204-214.

Tarasewicz, Z. and Aniśko, M. (2015): The Effect of Dried Fruit-vegetable-Herb Concentrate Applied in Compound Feed-stuffs On Reproductive Performance Of Broiler Chicken Parent Stock. (Vet Med Zoot). T. 69 (91):79-84.

Tunsaringkarn, T.; Wanna Tungjaroenchai, W. and Siriwong, W. (2013): Nutrient Benefits of quail (Coutrnix Coutrnix Japonica) eggs. International Journal of Scientific and Research Publications, Volume 3, Issue 5, 1-8.

Vasupen, K.; Wongsuthavas, S.; Bureenok, S.; Saenmahayak, B.; Ampaporn, K.; and Yuangklang, C. (2013): Effect of Tomato Pomace and Fibrolytic Enzyme on Egg Production and Egg Quality. World Academy of Science, Engineering and Technology Vol: 7.

Yitbarek, M.B. (2013): The effect of feeding different levels of dried tomato pomace on the performance of Rhode Island Red (RIR) grower chicks. Global Journal of Poultry Farming and Vaccination. Vol. 1 (1), pp. 052058. 